\title{
TADEUSZ BIESAGA, SPÓR O PODSTAWY ETYKI MEDYCZNEJ. TELEOLOGIZM E.D. PELLEGRINO A KONTRAKTUALIZM R.M. VEATCHA, UNIWERSYTET PAPIESKI JPII W KRAKOWIE, KRAKÓW 2014, SS. 380.
}

Monografia ks. Biesagi pt. Spór o podstawy etyki medycznej. Teologizm E.D. Pellegrino a kontraktualizm R.M. Veatcha jest pozycją naukowo ważną, aktualną i pod kilkoma względami inspirującą. Zacznijmy od wyjaśnienia, dlaczego praca Biesagi jest ważna. Ponieważ dotyka ona jednej z najtrudniejszych i najbardziej kontrowersyjnych kwestii filozoficznych, jaką są podstawy etyki medycznej, z uwzględnieniem ich założeń teoretycznych i praktycznych reguł, które odnoszą się do zasad i procedur obowiązujących w praktyce medycznej. $Z$ tych też powodów badania nad podstawami etyki medycznej łączą ze sobą różne wymagania, takie jak obiektywność i wiarygodność. Czy też, na innej płaszczyźnie, domaga się zachodzenia pewnej zbieżności argumentacji filozoficznej z szeroko rozumianym doświadczeniem medycznym i społecznym. Na aktualność proponowanych rozwiązań bioetycznych wpływa powiązanie ze sobą filozofii i medycyny, z ich szczegółowymi uwarunkowaniami kulturowymi i społecznymi. Dodajmy, że współczesne spory na temat podstaw etyki medycznej dotyczą głównie kwestii obiektywności i uniwersalności zasad etycznych i zakresu ich obowiązywalności Każda więc nowa filozoficzna propozycja etyki bioetycznej staje się nie tylko rzecznikiem określonych racji, ale też stroną sporu. Wskazując na nowe możliwości aplikacji filozoficznych zasad i reguł, bioetyka przede wszystkim nadaje etyczne znaczenie takim pojęciom, jak: ludzkie życie, cierpienie, granice interwencji w ludzki organizm oraz śmierć. Pojęcia 
te są rozważane w obrębie etycznych kategorii, takich jak: wolności i odpowiedzialności, powinności i wartości, celowości oraz skuteczności. Występują one zarówno na gruncie filozofii klasycznej, jak i współczesnej, wiążąc się albo z kategoriami metafizycznymi, albo ze społecznymi. Każde $z$ tych ujęć $w$ inny sposób pojmuje etyczne podstawy etyki medycznej, tym samym przyczyniając się do sporu wokół dwóch, zasadniczych kwestii: 1) o zakres wolności podmiotowej, dotyczącej własnego organizmu i prawa lub zakazu wolnego rozporządzenia własnym życiem oraz 2) o zakres praw i obowiązków środowiska medycznego wobec pacjentów.

W pracy Biesagi kwestie te zostały dogłębnie omówione w ramach filozoficznych koncepcji. Takie ujęcie pozwala na ukazanie związków, jakie zachodzą między twierdzeniami bioetycznymi a założeniami ogólnofilozoficznymi. Ich prawomocność wpływa nie tylko na wewnętrzną logikę danego wywodu, ale też na możliwość weryfikacji twierdzeń bioetycznych. Sporne kwestie domagają się przecież konfrontacji argumentów, racji za nimi stojących oraz analizy bezpośrednich skutków ich aplikacji w medycynie. Biorąc pod uwagę rangę poruszanych w bioetyce kwestii, Biesaga ten spór traktuje nie tylko jako przyczynek do podjęcia badań z zakresu bioetyki, ale przede wszystkim jako rodzaj wyzwania, inspiracji do zainteresowania się antropologicznymi podstawami etyki medycznej, w nich upatrując głównego przedmiotu polemik w obrębie koncepcji bioetycznych oraz źródła wszystkich etycznych zasad i reguł, jakie mają zastosowanie w medycynie.

W omawianej pracy Biesagi spór, to nie tylko fakt, do którego się odwołuje, ale też klucz do zrozumienia konstrukcji całej książki; jako źródło inspiracji oraz klucz do zrozumienia przyjętej w Sporze o podstawy etyki biomedycznej interpretacji, w której obrębie zostały omówione dwie różne koncepcje bioetyczne - spór między nimi oraz polemiki, jakie one prowadzą w obrębie własnych stanowisk, determinują konfrontacyjną postawę ze strony autora. W końcowych partiach swojej książki Biesaga dzieli się swoimi uwagami 
i komentarzami, które wprowadzają czytelnika w spór z Pellegrino i Veatchem, a szerzej w dyskusję, jaka toczy się między zwolennikami absolutystycznych podstaw moralności a autorami koncepcji o charakterze pragmatycznym czy relatywistycznym. Przedstawiając własne stanowisko w kwestii podstaw antropologicznych, Biesaga odwołał się głównie do tradycji personalistycznej. Wraz z przyjęciem tezy, że antropologia stanowi fundament dla etyki medycznej, autor Sporu o podstawy etyki biomedycznej konsekwentnie wszystkie dyskusje, które mają miejsce w obrębie bioetyki, sprowadza do tej najważniejszej kwestii. Od przyjętej teorii człowieka - związanej z problematyką wartości, dobra i nadrzędnego celu - zależy wybór zasad moralnych. Biesaga przyjmuje zatem, że spory wokół zagadnień antropologicznych wynikają najczęściej z konfrontacji odrębnych światopoglądów, różnych koncepcji filozoficznych oraz akceptacji określonych zasad w etyce medycznej. Polemiki wokól tych kwestii bioetycznych przenoszą dyskusję o podstawach moralności w obszar etyki medycznej. Dlatego też tytuł pracy Biesagi wskazuje na spór jako otwarte i aktualne pole konfrontacji nie tylko różnych koncepcji bioetycznych, ale też teorii antropologicznych i normatywnych. Konsekwentnie, problematyka sporu zaważyła na kompozycji i strukturze całej pracy, w jej obydwóch warstwach: merytorycznej i formalnej.

Mimo złożonej, wielowątkowej kompozycji omawianej pracy, ma ona charakter spójny i uporządkowany. Dodajmy, że spory o podstawy bioetyki rozciągają się nie tylko na środowiska naukowe, ale są również obecne w życiu publicznym i medialnym. Przy tym wyraźnie staje się widoczny wzrost zainteresowania czynnikami społecznymi, co zostało zauważone zarówno w pracach Pellegrino jak i Veatcha. Rozważaniom tym towarzyszy pytanie, podniesione przez tych bioetyków: na ile społeczeństwo demokratyczne może stać się partnerem do dyskusji z bioetykami w poszukiwaniu właściwych rozwiązań? A na ile ono samo powinno zostać objęte odpowiednią, bioetyczną edukacją? Odpowiedź na to jak i na inne pytania nie jest jednoznaczna, biorąc pod uwage stan współczesnych sporów 
interpretacyjnych na terenie filozofii. Istniejące podziały dobrze ilustruje omawiana monografia, w której opisuje się oraz poddaje szczegółowej analizie dwa różne stanowiska z zakresu etyki medycznej. Reprezentują je wybitni naukowcy, których prace zostały przez Biesagę przetłumaczone, opracowane i uporządkowane tematycznie. Wybór ten został zapewnie podyktowany poznawczymi walorami prac Pellergino i Veatcha. Na tę pozytywną ocenę składają się trzy czynniki: szeroki zakres poruszonych problemów, rozbudowana teoretyczna część etyki medycznej oraz uwzględnienie nowych wyzwań, przed którymi stoi współczesne środowisko medyczne. Szukając właściwej, racjonalnej argumentacji, obydwaj naukowcy kierują się chęcią zagwarantowania etyce medycznej mocnych, obiektywnych podstaw. Dlatego też w swoich koncepcjach podejmują polemikę z tymi ujęciami etyki medycznej, które ich zdaniem nie spełniają tych warunków.

Omawiani przez Biesagę bioetycy byli związani ze środowiskiem uniwersyteckim Georgetown w Waszyngtonie, gdzie w Instytucie Etyki Kennedych od lat 70. są prowadzone badania nad bioetyką. Od początku towarzyszyły tym badaniom spory oraz akademickie polemiki, które znalazły swój wyraz m.in. w pracach Pellegrino i Veatcha ${ }^{1}$. Obydwaj uczeni są powszechnie uważani za wybitnych i oryginalnych myślicieli. Wybór tych autorów tak Biesaga tłumaczy: „Rekonstrukcja i konfrontacja dwu odmiennych podstaw etyki medycznej, czyli teleologicznej etyki dobra pacjenta i kontraktualistycznej etyki zasad powinna wskazać kierunek jej dalszego rozwoju” (s. 6). Jakie zatem kryteria etyki medycznej przyjęli Pellegrino i Veatch? Dlaczego opowiedzieli się za takimi a nie innymi podstawami zasad etyki medycznej? By podjąć się odpowiedzi te pytania, trzeba

1 Biesaga przypomina we Wstępie, że w środowisku naukowym Uniwersytetu Georgetown „Zasadniczo zrodziły się (...) trzy propozycje: hipokratejska etyka dobra pacjenta Edmunda D. Pellagrino i Davida C. Thomasamy, etyka czterech zasad zwana pryncypializmem Toma L. Beauchampa i Jamesa F. Childressa oraz etyka kontraktualistyczna Roberta M. Veatcha" (s. 5). 
najpierw krótko omówić charakter badań, przeprowadzonych przez ks. Biesagę.

$\mathrm{Na}$ pierwszym planie w swojej pracy ks. Biesaga zajmuje się rekonstruowaniem, omówieniem, analizą i komentowaniem poglądów dwóch wspomnianych już bioetyków. Na drugim zaś porusza i analizuje w świetle wybranych stanowisk filozoficznych różne problemy i zagadnienia bioetyczne. $\mathrm{Na}$ trzecim z kolei zostały szczegółowo podjęte zagadnienia metodologiczne, refleksje nad prawomocnością argumentów i wynikających $z$ nich twierdzeń. Oczywiście, te trzy plany są ze sobą powiązane i tworzą złożoną, monograficzną całość. Pod tymi kątami został zatem omówiony i zinterpretowany dorobek naukowy Pellegrino i Veatcha. Rozpisany został na szereg ważnych kwestii, ze względu na które można określić jego specyfikę i wyodrębnić zawarte w danej koncepcji główne zasady i reguły postępowania. Interpretacja tekstów tych myślicieli wymagała odniesienia ich do wielu innych stanowisk, porównania ze starożytnymi i współczesnymi ujęciami. Tej wszechstronnej analizie zostały poddane nie tylko pojęcia i kategorie, ale też metody i argumentacja, do jakich odwołują się w swoich tekstach Pellergino i Veatch. Badania tak szeroko zakrojone nad koncepcjami omawianych bioetyków, a w konsekwencji także nad współczesną kondycją etyki medycznej, wymagały od autora teoretycznej i historycznej erudycji w zakresie problematyki filozoficznej, etycznej i bioetycznej ${ }^{2}$ „„Brak świadomej refleksji dotyczącej epistemologicznych, antropologicznych czy metafizycznych założeń i implikacji, danej etyki może być bowiem formą zastępowania racjonalnego uzasadnienia filozoficznego, manipulacją naszym myśleniem i postępowaniem” (s. 7).

Na całość rozważań, podjętych w pracy Biesagi, składają się więc trzy rozdziały; w pierwszych dwóch częściach autor zajął się

2 Tadeusz Biesaga jest autorem kilkunastu artykułów, poświęconych problematyce bioetycznej a także redaktorem pracy zbiorowej pt. Podstawy i zastosowania bioetyki, Wyd. Nauk. PAT, Kraków 2001. 
szczegółowym przedstawieniem stanowiska niedawno zmarłego Edmunda D. Pellegrino a następnie Roberta M. Veatcha, by w trzecim i ostatnim zarysować własne stanowisko w części zatytułowanej $W$ kierunku ugruntowanej antropologicznie etyki medycznej. Warto zatem, nie streszczając wymienionych rozdziałów, przywołać najważniejsze tezy, a także zapoznać się z przyjętymi założeniami w omawianej monografii Biesagi. W swoich koncepcjach bioetycznych Pellergino i Veatch wyrażają bowiem pewne aktualne tendencje, odwołują się do określonych teorii dobra człowieka (pacjent-lekarz), roli i funkcji społecznej medycyny, ale też wskazują, gdzie należy szukać poszukiwanych odpowiedzi. Czy w świecie struktur metafizycznych czy w sferze doświadczenia społecznego? Pytanie to wiąże się z koniecznością podjęcia refleksji nad tym, jakie wartości mają określać cele medycyny. W istocie chodzi o to, by z jednej strony zapewnić prawa pacjentom i sformułować podstawy zobowiązań lekarzy, biorąc również pod uwagę warunki odpowiedzialności tej grupy zawodowej. A z drugiej, należy uporządkować procedury medyczne, ustalić zasady etyczne obowiązujące w relacjach pacjent-lekarz (czym w istocie jest dla nas przysięga Hipokratesa, jak dzisiaj należy ją interpretować?), powołać się na cele medycyny. Trzeba też uwzględnić gwałtowne i wielokierunkowe zmiany cywilizacyjne, z jakimi mamy dzisiaj do czynienia. Wspomniane zmiany dokonują się m.in. pod wpływem zaawansowanych technologii oraz czynników instytucjonalnych i ekonomicznych (lecznictwo publiczne i prywatne, koszyki świadczeń medycznych itd.). Co sprawia, dodajmy, że nie można w badaniach bioetycznych ograniczać się tylko do pytań o etyczne podstawy medycyny. Trzeba uwzględniać społeczne oczekiwania i potrzeby, wyrażane także przez środowisko medyczne. Ponieważ wpływają one na preferencje określonych zasad i reguł etycznych. Biorąc pod uwagę te wszystkie, złożone kwestie, można ogólnie stwierdzić, że stanowiska opowiadające się za absolutystycznymi rozwiązaniami zwykle traktują czynniki społeczne i cywilizacyjne jako przypadkowe, nieistotne. $Z$ kolei koncepcje opowiadające się 
za dyskursywnym modelem etyki medycznej, nie uwzględniają jej trwałych podstaw w postaci celów, wartości i norm. Oceniając je jako dogmatyczne, a więc nieweryfikowalne przez doświadczenie. W tej sytuacji Biesaga przyjmuje, że spory wokół bioetyki koncentrują się na filozoficznie uzasadnionej koncepcji człowieka i jego dobra. $\mathrm{Na}$ tej antropologicznej płaszczyźnie można też szukać rozsądnego kompromisu między różnymi ujęciami filozofii człowieka. Ta ostatnia uwaga pochodzi ode mnie, ponieważ ani Pellergino, ani Veatch, ani też Biesaga nie podjęli się tego ryzykownego zadania. Kompromis, jak wiadomo, nie rozwiązuje żadnej ze spornych kwestii, ale umożliwia wspólną rozmowę o nich.

Zwolennicy absolutyzmu w bioetyce starają się wzbogacić klasyczne teorie, o nową, współczesną problematykę, o nowe kategorie i wzbogacone formy argumentacji. Tak jest właśnie w przypadku Pellergino, absolwenta wydziału filozofii kolegium jezuickiego, który przez 65 lat był praktykującym lekarzem. W swoich pracach z zakresu bioetyki Pellegrino przedstawia siebie jako lekarza rzymskokatolickiego ${ }^{3}$. Biesaga, rekonstruując dorobek naukowy Pellegrino, wskazuje na jego wieloletnie zainteresowanie trzema zagadnieniami. Dotyczą one moralnych związków, wiążących pacjenta z lekarzem i można je zasygnalizować w następujący sposób: 1) związki te należy spersonalizować, 2) trzeba postawić pytanie o to, jak rozumie się dobro pacjenta i cel medycyny - na czym się opierają i gdzie mają swoje ugruntowanie oraz 3) zbadać, jakie cnoty powinien posiadać lekarz, aby ów cel właściwie realizować. Rozważaniom tym towarzyszy próba wypracowania paradygmatu filozofii medycznej; oparcia go na stałych i obiektywnych kryteriach antropologicznych $i$ teleologicznych. $\mathrm{W}$ proponowanym przez Pellegrino ujęciu, filozofia medyczna ustala pryncypia, zasady i bada związki, jakie między nimi

3 „Zostałem uwrażliwiony (...) w kwestii niezbędności etyki medycznej w praktyce medycznej oraz w mojej osobistej integralności rzymskokatolickiego lekarza"', cyt. za: T. Biesaga, dz. cyt., 12. 
zachodzą. Z kolei etyka medyczna opracowuje procedury, dzięki którym zasady te mogą stać się podstawą działania. Pellegrino jest przekonany o tym, że najlepiej ujmuje je etyka o korzeniach arystotelesowsko-tomistycznych, odwołująca się do stałego i niezmiennego prawa naturalnego.

Tym samym amerykański badacz opowiada się za wersją etyki fundamentalistycznej, a więc za etyką, która zakłada uniwersalizm i obiektywność prawd moralnych, wyraźnie odcinając się od stanowisk prezentowanych w etykach postmodernistycznych. Taki wybór pociąga za sobą też kilka trudnych do przeoczenia konsekwencji. Między innymi i tę, że przejście z poziomu teoretycznego na praktyczny wymaga powszechnej akceptacji deklarowanych zasad i wynikających z nich szczegółowych norm. Niezbędne jest też mocne wsparcie ze strony porządku prawnego i instytucjonalnego. Pellegrino zdaje sobie $z$ tego sprawę i dlatego postuluje powszechne dążenie do "powrotu do poważnej refleksji nad naturą dobra, teleosem aktywności zawodowej i sposobem odnoszenia się do tego, co spotyka ludzki byt $\mathrm{w}$ trudach realizacji poszczególnych potrzeb" ${ }^{\text {". Przy }}$ tym Pellegrino stara się powiązać ze sobą filozoficzną interpretację pierwszych zasad z określeniem celu, jaki przyświeca środowiskom medycznym. Pragnie uczynić to w sposób adekwatny i praktycznie skuteczny, rozpisując na cztery płaszczyzny normatywną treść związków, wiążących ze sobą teoretyczny namysł nad etyką medyczną z zawodowymi celami środowisk medycznych. Reprezentują one kolejno: filozofię i medycynę, filozofię w medycynie, filozofię medyczną oraz filozofię medycyny.

Biesaga, wyodrębniając poszczególne formy omawianego związku, jednocześnie podkreśla, że „najważniejszą z nich jest oczywiście

4 Cyt. za: T. Biesaga, dz. cyt., 36. Trudno się oprzeć wrażeniu, że praktyczna moc takiego postulatu uzależniona jest nie tyle od wiary i przekonań ich autora, ale tego, na ile te poglądy znajdują swoje odzwierciedlenie w świadomości społecznej, czyli we wspólnocie interpretacyjnej. 
filozofia medycyny". $Z$ dalszych rozważań jasno wynika, że związek filozofii z medycyną nie sprowadza się do „przewodniej” roli filozofii, ale do rodzaju twórczego dialogu (określenie ks. Biesagi), jaki powinien między nimi zachodzić. Ten rodzaj interakcji jest o tyle ważny, że medycyna ewoluuje podobnie jak i jej wiedza o człowieku, np. w związku z badaniami neuropatologicznymi czy neurochirurgicznymi. A twierdzenia filozoficzne podlegają ciągłej, historycznej interpretacji, zmienia się też ich język, metody, argumentacja. Dlatego Pellegrino powołuje się na wszystkie naturalne więzi, jakie łączą ze sobą filozofię z medycyną, wskazuje też na to, jakie różnice pojawiają się między nimi ${ }^{5}$. Warto tu przypomnieć, że pytania o to, na czym powinien polegać związek, jaki łączy filozofię z etyką (z jaką filozofią i z jak pojętą medycyną?), stanowią jeden z najważniejszych punktów spornych na terenie bioetyk ${ }^{6}$. Dyskusje te obejmują także kwestie odnoszące się do celu medycyny, a w wypadku Pellegrino i innych bioetyków powołujących się na filozofię arystotelesowską, podnoszone są trudności związane z rozwiązaniem dwóch kwestii. Chodzi o to, na ile cele medycyny są zgodne $z$ ostatecznym celem (dobrem) człowieka oraz jak medycyna powinna respektować to dobro w zakresie wszystkich przypadków i stanów chorobowych.

Dużo miejsca w komentarzach Biesagi zajmują uwagi na temat podziału, jaki zachodzi między celami wewnętrznymi medycyny a zewnętrznymi, utożsamianymi z ,konstruktem społecznym”, jak ten czynnik określił Pellegrino. Wspomniany podział wprowadza dwa różne ujęcia etyki medycznej, dzielącej się na kierunki esencjalistyczne i konstrukcjonistyczne. Pellegrino uznaje, zgodnie z założeniami swojej filozofii, pierwotność i wyższość podejścia esencjalistycznego nad konstrukcjonistycznym. Przy tym przyjmuje,

5 Według Pellergino: „Medycyna jest (...) czymś więcej niż szukaniem prawdy wskazanej przez cel praktyczny, który służy tej prawdzie, a mianowicie zdrowiu, uzdrawianiu ludzkiej istoty", cyt. za: T. Biesaga, dz. cyt., 51.

6 W swojej monografii Biesaga omawia i poddaje klasyfikacji stanowiska, jakie zajmują w tej sprawie bioetycy (43-64). 
że immanentne cele medycyny są realne i odpowiadają wewnętrznej intencjonalności praktyki medycznej. Konsekwentnie Pellargino zakłada, że z głównego celu medycyny wynikają inne, szczegółowe cele, podjęte na terenie medycyny klinicznej prewencyjnej, pielęgniarskiej, społecznej i środowiskowej. W ten sposób Pellegrino stara sie powiązać ze sobą główny cel medycyny z jej celami praktycznymi.

Biesaga relacjonuje i uzupełnia te rozważania, wskazując na ich immanentną więź z problematyką teoretyczną i praktyczną zagadnień, jakie w szerokim zakresie porusza amerykański bioetyk. W tym zbiorze ważne miejsce zajmuje problematyka dobra pacjenta, którą Pellegrino ujmuje w czterech różnych, wyodrębnionych znaczeniach. Należy też, zdaniem amerykańskiego badacza, uwzględnić odpowiednie wykształcenie jak i etyczne kompetencje lekarzy. Dobro pacjentów i dobroczynność ze strony środowiska medycznego dotyczy tak wartości, jak powinności (co powinno się robić, a co jest zabronione), wspartych odpowiednim prawem. „Ów punkt kulminacyjny - zaznacza Biesaga w ramach rozważań Pellegriniego o etyce medycznej - skupiony na słusznym i dobrym działaniu leczniczym jest tym, co konstytuuje medycynę jako taką" (s. 99). Co nie znaczy, że wiedza o tym, co słuszne i etycznie dobre, jest dana w sposób oczywisty, Pellegrino przywołuje przypadki konfliktowe (dobro pacjenta - dobro społeczeństwa lub moralne i religijne różnice, jakie dzielą światopogląd lekarza od światopoglądu pacjenta).

W tych konfliktowych sytuacjach podstawą do porozumienia się jest wzajemny szacunek dla godności i wyznawanych wartości. „W moralnie pluralistycznym społeczeństwie jest oczywiste, że uniwersalna zgoda między lekarzem a pacjentem w sprawie fundamentalnych kwestii moralnych jest już niemożliwa" (s. 102). Co zatem proponuje Pellegrino? Obydwie strony według niego, powinny ustalić to, co je łączy, niezależnie od różnic, zachodzących między nimi, by w obrębie wspólnych wartości określić zakres możliwej wspólpracy. Można też, biorąc pod uwagę różne relacje wiążące pacjenta $z$ lekarzem i lekarza z pacjentem, mówić o etyce obowiązującej lekarzy 
i odpowiednio o etyce pacjenta. Pewną teoretyczną klamrą, która łączy ze sobą te dwa rodzaje etyk, są teleologiczne, agatologiczne i aretologiczne założenia etyki Arystotelesa. W tych dociekaniach, co podkreśla Biesaga, Pellegrino bierze pod uwagę inne stanowiska, które przeciwstawią godności, dobru i autonomii osoby-pacjenta model biomedyczny, techniczny. Lub relatywnie traktują dobro pacjenta w stosunku do jakości konkretnego życia. Pellegrino, filozof i zarazem praktykujący lekarz, przyjmuje dwie zasady za podstawowe dla etyki medycznej. Są to: dobro osoby, ujęte jako cel odkryty i uzasadniony, na poziomie filozofii medycyny i dobroczynność jako zasada (norma) praktyczna.

Materiał zebrany w 23 książkach tego bioetyka został przez Biesagę przemyślany, uporządkowany i odpowiednio sklasyfikowany. Można wymienić szereg trudności stojących przed badaczem poglądów Pellegrino. Do najważniejszych należą przynajmniej dwie z nich: wielka rozpiętość tematyczna badań związana z bardzo bogatą terminologią. Mimo że autor nawiązuje do określonej tradycji filozoficznej (Arystoteles, św. Tomasz), to poddaje ją głębokiej reinterpretacji. Przyczyną tych celowo wprowadzonych zmian jest próba zbudowania całościowego systemu bioetycznego, złożonego $\mathrm{z}$ teoretycznych i praktycznych moralnych zagadnień, jakie odnoszą się do współczesnej medycyny. Tak rozbudowana koncepcja etyki medycznej ma podwójne aspiracje; chce wskazać na stałe i obiektywne fundamenty zasad oraz na ich współczesny, społeczny kontekst. Tym samym Pellegrino polemizuje $z$ innymi propozycjami etyki medycznej. Autor ten starannie wypunktował zagrożenia, przed którymi stoi lekarz i pacjent, w tym także bierze pod uwagę rolę edukacji społeczeństwa w kształtowaniu właściwych postaw moralnych.

Dodać można, że bez gruntownej znajomości filozofii i etyki, przede wszystkim Arystotelesa, nie można byłoby odtworzyć dorobku Pellegrino i poddać go gruntownej analizie. Omówienie kolejnego, ważnego stanowiska Veatcha, wymagało od Biesagi dobrego przygotowania z zakresu filozofii nowożytnej i współczesnej. 
Veath to młodszy kolega Pellegrino, pracujący w tym samym Instytucie, który proponuje zupełnie inne spojrzenie na podstawowe kwestie etyki medycznej. Jego stanowisko zostało przez Biesagę szczegółowo omówione w drugiej części Sporu o podstawy etyki medycznej i od razu należy zauważyć, że stanowi ono znakomity kontrapunkt dla poprzednio omówionej koncepcji Pellegrino. Veath przyjmuje różne od Pellegrino założenia filozoficzne i związane z nimi inne procedury wyjaśniające. Bioetyk ten stawia sobie za zadanie kierowanie się dwoma przesłankami: realnością społeczeństw demokratycznych i odrzuceniem, zanegowaniem relatywizmu w bioetyce. $\mathrm{W}$ rezultacie, w swojej koncepcji Veatch odwołuje sie zarazem do pluralizmu, jak i do uniwersalizmu moralnego. W konsekwencji tych deklaracji programowych badacz ten krytyce poddaje metafizyczne podstawy etyki medycznej i jej ujęcia pragmatyczne. Veatch w swoich programowych deklaracjach podkreśla, że „Należy rozwinąć nową etykę, bardziej egalitarną, bardziej społeczną, bardziej zorientowaną na prawach (...) o szerokim, publicznym wymiarze"7. Przekonanie to ma też swoje źródła i we współczesnej filozofii angloamerykańskiej (przede wszystkim w koncepcjach Rawlsa i Firtha), a nie tylko w przemianach świadomości, postawach społecznych i w uprawnieniach lekarzy. Przyjęcie społecznej umowy (kontraktu) za punkt wyjścia stanowi nie tylko uniwersalną procedurę, umożliwiającą formułowanie uniwersalnych zasad, ale też pozwala na zrezygnowanie $\mathrm{z}$ relatywizmu i partykularyzmu. W swoich obszernych komentarzach Biesaga nie tylko szczegółowo rekonstruuje poglądy Veatcha na ten temat, ale też uzupełnia je i wzbogaca o różne konteksty filozoficzne. Wyjaśnienia te są cenne, ponieważ amerykański badacz, odwołując się do zasady kontraktu, szuka takiego rozwiązania, które by pogodziło ze sobą stanowiska określonych grup społecznych. W tym też celu nawiązuje do koncepcji Rawlsa i Firtha, by wskazać na dwie idee regulatywne, tkwiące w kategorii kontraktu społecznego. Są to następujące idee:

7 Cyt. za: T. Biesaga, dz. cyt., 204. 
wspólnoty i zobowiązania, źródłowej powinności. Na tej podstawie Veatch próbuje pogodzić ze sobą reprezentacyjne, społeczne stanowiska, z pominięciem ich partykularnych interesów. Bierze pod uwagę także i to, że w zachodnich, pluralistycznych społeczeństwach, obecne są pewne typy sekciarstwa religijnego (reprezentowanego przez różne grupy wierzących), które głoszą sprzeczne, a nawet wrogie $\mathrm{w}$ stosunku do siebie poglądy moralne. $Z$ tych powodów, Veatch uważa, że poglądy religijne przynależą do sfery kulturowo-humanistycznej, na której nie można budować uniwersalnej etyki.

By zrealizować swój program etyki medycznej, amerykański filozof proponuje „potrójny kontrakt”, który kolejno dotyczy i obejmuje: podstawowy kontrakt społeczny, kontrakt, jaki zachodzi między społeczeństwem a środowiskiem medycznym, oraz kontrakt, wiążący ze sobą profesję medyczną z pacjentem (s. 205). Od razu dodajmy, że Veatch kontrakt traktuje jako instrument epistemologiczny, a nawet jako pewną metaforę, która zawiera podwójną intencję: społeczną, wspólnotową i uniwersalną jako fundament etyki. Biesaga, zastanawiając się nad znaczeniem tej propozycji, zadaje szereg, celnych pytań, które uświadamiają czytelnikowi, że sprawa jest bardziej złożona, niż by się to pozornie wydawało. Przynajmniej z punktu widzenia metodologicznego i etycznego.

Pierwsze zasady umowy społecznej, o jakich pisze Veatch, to przede wszystkim zasada dotrzymywania kontraktu ${ }^{8}$ przez wszystkie strony, a także zasada autonomii, uczciwości, prawdomówności i sprawiedliwości. Według tego badacza nie ma jednej, naczelnej zasady moralnej, z której by wypływały konkretne normy, ale jest ich kilka. Gdzie należy zatem szukać uniwersalizmu tych zasad? Gdzie tkwi ich wymiar powszechny i kto powinien o nim decydować?

8 Veatch wyjaśnia: „Pierwotna umowa społeczna jest regulowana przez etyczną zasadę dotrzymywania umów, i sama z kolei uświadamia nam, że dotrzymywanie obietnic jest normą regulującą dalsze stosunki społeczne. To stwarza podstawę dla drugiego stadium kontraktualnej teorii etyki medycznej"; cyt. za: T. Biesaga, dz. cyt., 214. 
Kontrakt tłumaczy, skąd je znamy i dlaczego powinniśmy wrazić na nie zgodę, kwestią otwartą pozostaje ich uniwersalny wymiar. „Uniwersalizm (...) utrzymuje, że istnieje jedno źródło i podstawa moralności. Podstawa ta jest poznawalna przez wszystkich i stosuje się do wszystkich" (s. 220).

Wprowadzając do swoich rozważań bezstronnego obserwatora, Veatch jest przekonany o tym, że pierwotny, intuicyjny wgląd w moralność pozwala rozsądnym ludziom rozpoznać uniwersalne zasady. Chociaż można za Biesagą wskazać na słabe punkty takiego założenia, to sama idea wydaje się, mimo oczywistych wątpliwości, bardzo inspirująca. Szukanie fundamentu, czegoś koniecznego i zarazem pewnego (na wzór kartezjański), prowadzi do metafizyki, religii czy koncepcji prawa naturalnego. A więc jest samo w sobie czymś sprzecznym, zdaniem Veatcha, $\mathrm{z}$ dążeniem do ustalenia bezstronnych podstaw uniwersalizmu etycznego. O stronniczości wymienionych poglądów świadczą zróżnicowane sensy, jakie nadaje się takim terminom, jak: eutanazja czy morderstwo w różnych grupach społecznych, religijnych czy światopoglądowych. Veatch przyjmuje, że istnieje jednak pewna pierwotna wspólnota moralna - dana intuicyjnie jako wspólne doświadczenie ludzi rozsądnych, co przypomina także Arystotelesowskie kryterium złotego środka. Zwykle, gdy się chce na terenie etyki uniknąć rozstrzygnięć metafizycznych, to przyjmuje się rozsadek i intuicję za podstawę ogólnie ważnych sądów moralnych. Biesaga analizuje bliżej konsekwencje takiego stanowiska, podnosząc problematykę aborcji czy eutanazji, lub też omawiając tzw. społeczną definicję śmierci, „w której akcent zostanie położony na utratę przez człowieka racjonalnej świadomości i możliwości społecznych relacji” (s. 242). Ustalenia te wskazują na otwarte pole interpretacji poglądów Veatcha, które zwłaszcza dotyczą najtrudniejszych kwestii bioetycznych. Myśliciel ten, opowiadając się za uniwersalizmem, jednocześnie nie jest zwolennikiem fundamentalizmu w etyce medycznej. $\mathrm{Za}$ podstawę swojej koncepcji Veatch przyjmuje bezstronny kontrakt społeczny, a jego doświadczalnej wiarygodności upatruje w ,istnieniu 
powszechnie podtrzymywanego zbioru przedteoretycznych moralnych intuicji” (s. 227). By przezwyciężyć relatywizm - zgodnie ze wstępnymi deklaracjami - amerykański myśliciel zakłada za Kartezjuszem, że wiedza moralna jest wiedzą pewną i oczywistą, opartą na już wspomnianej powszechnej intuicji.

Osobne miejsce w pracy zajmuje omówienie zasad etyki medycznej, postulowanej przez Veatcha. Wymienię je kolejno, nie rozwijając ciekawych komentarzy Biesagi, zmierzających do wyjaśnienia treści danej zasady i jej znaczenia. Są to następujące pryncypia: dobroczynność, zasada dotrzymywania kontraktu czy obietnic, zasada autonomii, uczciwości, unikania zabijania i sprawiedliwości. „Każdą z tych zasad - wyjaśnia Biesaga - Veatch rozważa na trzech poziomach; na poziomie hipotetycznego kontraktu społecznego (...), na poziomie kontraktu między społeczeństwem a profesjonalistami i na poziomie kontraktu miedzy lekarzem a pacjentem" (s. 231). Veath proponuje również rozwiązywanie konfliktów, jakie moga zachodzić między wspomnianymi zasadami. Propozycje te, zdaniem autora Sporu o podstawy etyki medycznej, odwoływały sie do etyki zredukowanej do heurystycznego dyskursu moralnego. Co, jak się, wydaje, jest zgodne $\mathrm{z}$ intencjami Veatcha, świadomie unikającego metafizycznego uzasadnienia moralności.

Biesaga swoje uwagi pod adresem kontraktualistycznej etyki Veatcha formułuje jasno, stwierdzając, że stanowisko amerykańskiego bioetyka ma swoje walory poznawcze, niemniej jednak brakuje mu właściwego ugruntowania moralności w filozofii człowieka. Mówiąc o „ubóstwie antropologicznym” Biesaga ma na myśli aktualną dyskusję wśród bioetyków ma temat tego, jak należy rozwijać problematykę etyki medycznej, do jakich sięgać źródeł, zasad i ich kryteriów. Bioetyka jest przecież obecna w różnych koncepcjach filozoficznych, $\mathrm{w}$ rozmaitych formach dyskursu społecznego i medialnego, w zapisach prawnych oraz w międzynarodowych dokumentach. Tu nie chodzi tylko o sposób rozumienia etyki, ale przede wszystkim o jej wiarygodność praktyczną. Dlatego też na tym gruncie dominują 
dwa stanowiska; jedno z nich traktuje bioetykę jako dyscyplinę filozoficzną, drugie natomiast szuka dla niej naukowych podstaw. Za każdym z tych dwóch stanowisk stoją tzw. dobre racje. Dlatego wydaje mi się, że próba pogodzenia ze sobą tych ujęć, a przynajmniej wskazania na to, co je łączy, jest wręcz konieczna ze względu na praktyczną doniosłość problematyki bioetycznej.

W końcowych partiach pracy Biesagi, zostały ze sobą skonfrontowane - ze względu na ich założenia antropologiczne - dwa wcześniej zanalizowane stanowiska Pellegrino i Veatcha. W nawiązaniu do aktualnych, bioetycznych dyskusji nad podstawami antropologicznymi w etyce medycznej, łatwiej można scharakteryzować poglądy tych dwóch amerykańskich bioetyków. Autor Sporu o podstawy etyki medycznej bada je pod kątem przyjętych w nich założeń oraz związków, jakie je łączą z różnymi nurtami filozoficznymi i antropologicznymi. Zagadnienia te stanowią wstępną, heurystyczną część trzeciego rozdziału i mają na celu pokazanie, jak wiele zamysłów, twierdzeń $i$ ustaleń programowych decyduje o rozwiązaniach przyjętych na terenie bioetyki. Ostatecznie autor omawianej monografii tak ocenia filozoficzne dokonania Pellergino w obrębie etyki medycznej: „opracował podstawowe elementy etyki medycznej, ale nie wyjaśnił, na czym polega związek tej dyscypliny z antropologią i metafizyką" (s. 291). $Z$ tej samej antropologicznej perspektywy Biesaga dokonuje oceny etyki Veatcha podkreślając, że ,zawierający fikcyjny kontrakt (...) przyjmują oni moralny punkt widzenia, ale nie wyjaśnił, co jest podstawą owej moralności” (s. 291). Uwagi te, poprzedzone szczegółowymi analizami, stanowią przyczynek do rozwinięcia przez Biesagę badań nad podstawami etyki i ich związkiem $z$ antropologią i z metafizyką. Autor Sporu o podstawy etyki medycznej jest przekonany o tym, że chociaż każdy z omawianych przez niego badaczy wybrał ciekawą drogę i pod wieloma względami inspirującą, to zabrakło w nich odpowiednio rozwiniętej antropologii. Pytanie, jakie postawił Biesaga, dotyczy więc wyboru odpowiedniej koncepcji 
antropologicznej; a więc takiej, która może być wiążąca zarówno dla etyki jak i dla medycyny.

Podejmując tę problematykę, autor Sporu o podstawy etyki medycznej sięga do filozoficznych koncepcji antropologicznych etyków-personalistów, głównie reprezentujących środowisko Katolickiego Uniwersytetu Lubelskiego. Do tego grona personalistów należą: Wojtyła, Styczeń, Krajewski, Szostek. W rozważaniach tych Biesaga dużo miejsca poświęca tej grupie europejskich filozofów, którzy opowiadają się za antropologicznymi korzeniami etyki, interpretowanej w duchu personalistycznym. Trzeba wyraźnie zaznaczyć, że autor Sporu o podstawy etyki medycznej zadał sobie dużo trudu, by opisać różne poglądy filozoficzne nawiązujące do kategorii godności osoby, jej źródeł, funkcji, specyfiki i moralnych implikacji. Przyjmując za punkt wyjścia wspólne rozumienie godności jako wartości ontycznej (a więc nieredukowalnej, wrodzonej i niezbywalnej wartości, przypisanej każdej osobie ludzkiej), wskazuje na pierwszeństwo dobra osoby nad innymi dobrami. $Z$ założeń tych wynika porządek moralny przyjęty w etyce medycznej i określającej jej hierarchię dóbr, wartości, celów i norm. Co w konsekwencji znaczy, że autonomia osoby jest następstwem jej godności, a zatem zależy od niej i jest jej podporządkowana.

W Zakończeniu, autor, formułując końcowe wnioski, zauważa, że „Przy całej rozbieżności obu propozycji [Pellegrino i Veatcha przyp. E.P.] podstaw etyki medycznej można jednak wskazać na pewne związki między nimi, a co więcej, należy dalej poszukiwać możliwości, jakie jeden moduł może zasugerować drugiemu" (s. 338). Przypomnijmy, że chodzi o te możliwości, które wiążą się z motywem interpersonalnym, podjętym w pismach Pellegrino. A także z czynnikiem społecznym, obecnym w koncepcji Veatcha. Właściwie pojęte dobro pacjenta może zapewnić kontraktowi społecznemu etyczny charakter, tj. oparty na stałym kryterium dobra osoby i jej godności. Rozwinięcie tej problematyki w obrębie zaistniałego sporu wymaga wielu, złożonych zabiegów poznawczych. Jest to przede 
wszystkim postulat, który nie może zostać zrealizowany w obrębie jednej koncepcji etycznej. Dlatego autor recenzowanej pracy, wskazuje na kierunek dalszych badań oraz na ich celowość. Kierunek ten, co warto zaznaczyć, powinien zmierzać do powiązania ze sobą dwóch wspomnianych wcześniej motywów etyki medycznej, personalnego i społecznego. Dodam od siebie, że antropologia pozwala na przyjęcie określonej hierarchii zasad (tj. norm i wartości), ale nie prowadzi bezpośrednio do konkretnych rozstrzygnięć na gruncie praktycznym sporów, dylematów czy wątpliwości.

W tej sytuacji należy zapytać o to, gdzie zatem należy szukać kryteriów, które umożliwiają podejmowanie w medycynie moralnie słusznych wyborów? Debaty dotyczące testamentu życia lub koniecznych regulacji w sprawie uporczywej terapii wskazują m.in. na trudności w ustaleniu jednoznacznych kryteriów moralnych. Podkreślmy, że albo za Pellergino można odwołać się do jednego kryterium, albo za Veatchem do kilku zróżnicowanych zasad i reguł. Każda z tych opcji ma swoje wady i ograniczenia, na co wskazują krytyczne analizy koncepcji bioetycznych omawianych filozofów. Zaznaczmy, że niewątpliwą zasługą recenzowanej pracy jest to, że inicjuje ona dyskusję wokół kwestii najważniejszych, wskazując na różne alternatywne rozwiązania i racje, które im przyświecają. Prezentując własne stanowisko w tych sprawach, Biesaga sam został uczestnikiem tej debaty, biorąc aktywny udział w dwóch sporach i czyniąc to w sposób pośredni i bezpośredni. Pośrednio, wskazując na potrzebę rozwinięcia badań, podjętych zarówno przez Pellegrino i Veatcha, zwłaszcza związanych z wątkiem interpersonalnym i czynnikiem społecznym, które domagają się modyfikacji i wzbogacenia zasad etycznych w medycynie. A bezpośrednio Biesaga zaangażował się w spór o podstawy antropologiczne w etyce medycznej i ich odpowiednią wykładnię.

Spory wokół etyki medycznej koncentrują się głównie na kwestiach podstaw etycznych - w ich uwarunkowaniach teoretycznych i praktycznych. Wywołuje to szereg pytań np. o prawomocność i treść 
zasad, o cel i jego realizację, o to jak współczesne technologie wpływają na procedury medyczne, czy prawo jest adekwatne do praktyki medycznej, jak pogodzić pluralizm światopoglądowy i religijny z moralnymi ustaleniami etyki medycznej? Jak należy moralnie interpretować sytuacje wyjątkowe, czy należy w tej dziedzinie zwalczać stereotypy, czy przeciwnie, podtrzymywać je? Poznając stanowiska Pellegrino i Veatcha, odnosi sie wrażenie, że każdy z tych badaczy zdawał sobie sprawę $z$ tego, jak złożona jest problematyka bioetyczna. Wybierając określony kierunek badań i rozwiązań, bioetycy ci odnosili się także do kwestii światopoglądowych, kompetencyjnych czy politycznych. Wątpliwości, które próbowali w różny sposób pokonać, dotyczą zarówno wyboru, jak i wielości etycznych podstaw - wobec zróżnicowanej problematyki i zróżnicowanych kryteriów wartościowania. Mam na myśli działania oceniane za moralnie słuszne oraz czyny kwalifikowane jako etycznie dobre. Obydwaj wspomniani myśliciele zwracają uwage na to, że procedury medyczne opierają sie na kwalifikacji działań moralnie słusznych. Tymczasem część etyków domaga się bezwzględnej afirmacji dobra osoby również na gruncie bioetyki.

Jak na to wskazuje lektura Pellegrino i Veatcha, problematyka ta należy do najbardziej spornych kwestii na terenie bioetyki. Ponieważ jest ona wyjątkowo podatna na relatywizm, pluralizm i pragmatywizm etyczny. Pellegrino, Veatch i Biesaga próbowali, rozwijając różne koncepcje antropologiczne, uniknąć tych wszystkich dylematów, jakie wnosi ze sobą potrzeba uzgodnienia ze sobą stałych i zmiennych uwarunkowań bioetyki. O ile etyka opowiada się za określoną kwalifikacją ludzkich działań, to praktyka społeczna i medyczna je w znacznym stopniu podważa, relatywizuje i deprecjonuje. By kwestie te uregulować, wydaje się, że należy przede wszystkim zrozumieć, że zadania etyki nie ograniczają się tylko do ustalenia zasad etycznych i wskazania na normy, które z nich wynikają. Etyka ponadto powinna spełniać dwie dodatkowe funkcje; heurystyczną i hermeneutyczną, tym samym przyczyniając się do humanistycznej refleksji nad sensem 
życia i działania człowieka, ujętych z różnych perspektyw moralnych, poznawczych, antropologicznych czy metafizycznych.

Monografia Biesagi wprowadza czytelnika na ten poziom ogólnej refleksji, dzięki swoim trzem zaletom, trudnym do przecenienia; jest dobrze i jasno napisana, szczegółowo rekonstruuje i omawia dwie ważne i aktualne koncepcje, wprowadza uwagi i komentarze, które rozszerzają filozoficzną wiedzę o różnych aspektach i zagadnieniach bioetyki. W związku z tym lektura monografii Biesagi przynosi ze sobą znajomość problematyki bioetycznej, wiedzę o najbardziej spornych kwestiach, a także stanowi okazję, by poznać dwie koncepcje reprezentatywne dla współczesnej bioetyki. Dodatkowo Biesaga, opowiadając się za antropologią personalistyczną, nie tylko przedstawia własne stanowisko, ale także dostrzega potrzebę prowadzenia badań nad czynnikami interpersonalnymi i społecznymi. Inna sprawa, czy w ramach antropologii personalistycznej, za jaką się opowiedział autor Sporu o podstawy etyki medycznej, można znaleźć miejsce na wspomniane uzupełnienia i modyfikacje.

$\mathrm{Na}$ zakończenie warto może podstawić kilka pytań, które są przedmiotem sporów na terenie bioetyki i do których nawiązuje praca Biesagi: 1) jaki jest zakres i źródła wprowadzenia założeń antropologicznych (ich maksymalizację lub minimalizację), 2) czy można powiązać ze sobą stanowisko Pellegrino i Veatcha w kwestiach antropologicznych, zakładając, że reprezentują one dwa, najbardziej charakterystyczne i aktualne podejścia do tej tematyki oraz 3) jakie jest - jeśli w ogóle jest - antropologiczne uzasadnienie dla treści podanych zasad moralnych przez wymienionych autorów?

EWA PODREZ

e.podrez@uksw.edu.pl

Uniwersytet Kardynała Stefana Wyszyńskiego w Warszawie, Instytut Filozofii

Wóycickiego 1/3, 01-938 Warszawa

DOI: 10.21697/spch.2017.53.4.32 